The rotation of penta-acetyl $d$-catechin from areca catechu:

$0.4446 \mathrm{~g}$. dried substance was dissolved in 25 c.c. acetylene tetrachloride. $[\alpha]_{v}^{19}=\left(+0.74^{\circ} \times 25\right):(1 \times 1.7784)=+41.6^{\circ}$.

\title{
On the Chemical Composition, especially Organic Bases of "Di-Saké".
}

\author{
By \\ Kotaro Nisfinda. \\ (Kagosilima Agricultural College, Kagoshima, Japan.) \\ (Received September 12, 1932.)
}

The "di-sake" or "di-shu" is a kind of "saké", which is alcoholic beverage peculiar to the Japanese ; and brewed in only two prefectures-Kagoshima and Miyazaki-in Japan. The annual production of "di-saké" in these districts amounts to about 3,400 3,600 koku or $6,200 \sim 6,500$ hectolitres in round number. Its raw-materials, the same with "sake": that is (1) steamed rice, (2) "koji", the fungoidal mass of Aspergillus Oryzae grown on steamed rice, and (3) Water; but this steamed rice as raw-material of "di-sake"" was made by the very roughly polished rice than that of the "sake", and then the method of brewing differ from "saké".

In the case of brewing of "di-saké", using in comparatively small amount of water and large amount of aged "koji", the saccharification of mash is promoted and the fermentation controlled; and to neutralize the acids in fermented mash, wood ash is added into the mash before the press; and then new "di-sake" obtained by the press is not pasteurized.

The "di-sake" is a sweet liquor of a yellow or yellowish brown colour and of the consistency more viscous than that of ordinal "sake"; and its use is not only for drinking, but for cooking instead of "mirin".

\section{Experimental Results.}

The "di-saké" experimented with was brewed at Kagoshima City; and the analytical results of the sample are shown in the following table; 


\begin{tabular}{|c|c|c|}
\hline & g. in $100 \mathrm{c} . \mathrm{c}$. & g. in $100 \mathrm{~g}$. \\
\hline Crude protein & 2.413 & 2.259 \\
\hline Protein & 0.056 & 0.052 \\
\hline Extract & 20.224 & 18.934 \\
\hline Reducing Sugar (as glucose) & 12.880 & 12.059 \\
\hline Dextrin & 1,652 & 1.547 \\
\hline Ash & 0.260 & 0.243 \\
\hline Specific gravity & \multicolumn{2}{|c|}{1.0681} \\
\hline Alcohol & 12.89 & \\
\hline$" \quad$ vol. \% & \multicolumn{2}{|c|}{16.24} \\
\hline$P_{\pi}$ & \multicolumn{2}{|c|}{6.823} \\
\hline
\end{tabular}

The various forms of nitrogen in the sample were also determined:

\begin{tabular}{l|c|c}
\hline & g. in 100c.c. & Ratio (Total N as 100) \\
\hline Total N & 0.386 & 100.0 \\
Protein N & 0.009 & 2.3 \\
Non-protein N & 0.377 & 97.7 \\
In which Ammonia N & 0.029 & 7.5 \\
Organic base N & 0.074 & 19.2 \\
Other N & 0.274 & 71.0 \\
\hline
\end{tabular}

\section{Isolation and Identification of Organic Bases.}

For the isolation of the organic bases 10 litres of the "di-sake" "were evaporated under reduced pressure to about 4 litres. After this operation the protein substance and other impurities were removed by neutral- and basiclead acetate, and excess of the lead by $\mathrm{H}_{2} \mathrm{SO}_{4}$, and then the organic bases were precipitated by phosphotungstic acid. And according to the general method the precipitate formed by phosphotungstic acid was fractionated into three fractions, and researches were made about the organic bases in each fraction.

(1) Purine Base-Fraction $\left(\mathrm{AgNO}_{3}\right.$-precipitate $)$ :-

The yield of the base from this fraction was $0.20 \mathrm{~g}$. as hydrochloride. Its picrate formed yellow prisms, changed to black colour at about $210^{\circ} \mathrm{C}$ (uncorr.). On analysing it as its chloroplatinate, following result was obtained :

$\begin{array}{ll}0.0752 \mathrm{~g} \text {. Subst. } 0.0217 \mathrm{~g} \text {. Pt, } & 28.86 \% \mathrm{Pt} \text {. } \\ \text { Calc. for Hypoxanthine-chloroplatinate }\left[\left(\mathrm{C}_{5} \mathrm{H}_{4} \mathrm{~N}_{4} \mathrm{O} \cdot \mathrm{IICl}\right)_{2} \mathrm{PtCl}_{4}\right] & 28.62 \% \mathrm{Pt} \text {. }\end{array}$

The chloroaurate of the base formed yellow prisms, decomposed at $254^{\circ}$ $C$ (uncorr.), and the result of the analysis was as follows: 


$$
\begin{aligned}
& 0.1647 \text { g. Subst. } \quad 0.0682 \text { g. } \Lambda \mathrm{u} \text {. } \quad 41.41 \% \Omega \mathrm{u} \\
& \text { Calc. for Itypoxanthine-chloroaurat }\left(\mathrm{C}_{5} \mathrm{H}_{4} \mathrm{~N}_{4} \mathrm{O} \cdot \mathrm{HC} \cdot \mathrm{AuCl}_{3}\right) \quad 41.42 \% " \text { " }
\end{aligned}
$$

These results in all respects agree precisely with hypoxanthine derivatives.

(2) Arginine-Fraction ( $\mathrm{AgNO}, \& \mathrm{Ba}(\mathrm{OH})_{2}$-precipitate) :-

The yield of the base from this fraction was $4.60 \mathrm{~g}$. as nitrate. The nitrate forms chalky substance, and the result of the analysis by Nitron method was as follows :

$$
\begin{aligned}
& 0.2049 \text { St. Sust. } 0.3193 \text { s. } \mathrm{C}_{000} \mathrm{II}_{16} \mathrm{~N}_{4} \cdot \mathrm{INO}_{3} \\
& 0.05364 \text { s. } 1 \mathrm{INO}_{3} \quad 26.18 \% \text { 自 } 1 \mathrm{INO}_{3} \\
& \text { Calc, for Arginine-nitrate }\left(\mathrm{C}_{6} \mathrm{H}_{1+} \mathrm{N}_{4} \mathrm{O}_{2} \cdot \mathrm{IINO}_{3}\right) \quad 26.55 \% \quad \mathrm{INNO}_{3}
\end{aligned}
$$

The coppernitrate formed deep blue needles, melted at $112^{\circ} \mathrm{C}$ (uncorr.) and decomposed at $230^{\circ} \mathrm{C}$ (uncorr.).

$\begin{array}{lll}0.1226 \mathrm{~g} \text {. Subst. } \quad 0.0179 \mathrm{~g} . \mathrm{CuO} \quad 0.0143 \mathrm{~g} . \mathrm{Cu} & 11.67 \% \mathrm{Cu} \\ \text { Calc. for Arginine-copper-nitrate }\left[\left(\mathrm{C}_{6} \mathrm{I}_{1.1} \mathrm{~N}_{4} \mathrm{O}_{9}\right) \cdot \mathrm{Cu}\left(\mathrm{NO}_{3}\right)_{2}\right] & 11.86 \% \mathrm{Cu}\end{array}$

According to the above results this base seems to coincide with arginine.

(3) Lysine-Fraction (Filtrate from $\mathrm{AgNO}_{3} \& \mathrm{Ba}(\mathrm{OH})_{2}$-precipitate) :-

The hydrochloride, which was freed from water obtained by this fraction, was treated with cold absolute alcohol and separated into two portions.

(a) Insoluble portion by cold absolute alcohol:-

Yield ; $0.50 \mathrm{~g}$. This chloride was identified as $\mathrm{KCl}$.

(b) Dissolved portion by cold absolute alcohol:-

Saturated alcoholic solution of $\mathrm{HgCl}_{2}$ was added to this portion.

The hydrochloride of the base obtained from the $\mathrm{HgCl}_{2}$-precipitate, forms colorless, very hygroscopic, large prisms and gives the alloxan reaction. The chloroaurate prepared from the hydrochloride forms yellow mossy crystals, and is sparingly soluble in water ; the melting point was determined as 256 $-257^{\circ} \mathrm{C}$ (uncorr.); and the analysis gave the following results:
$0.1541 \mathrm{~g}$. Subst. $0.0689 \mathrm{~g}$. Au
$0.2605 \mathrm{~g}$. " $0.1157 \mathrm{~g}$. "
$44.71 \% \mathrm{Au}$
Calc. for cholinechloroaurate $\left(\mathrm{C}_{5} \mathrm{H}_{14} \mathrm{NOCl} \cdot \mathrm{AuCl}_{3}\right)$
$44.41 \% " \%$
$44.49 \% \prime \prime$

The chloroplatinate formed orange yellow prisms, easily soluble in water, melted at $236-237^{\circ} \mathrm{C}$ (uncorr.) with decomposition, and gave the following analysis :

$$
\begin{aligned}
& 0.2345 \mathrm{~g} \text {. Subst. } \quad 0.0734 \mathrm{~g} . \mathrm{Pt} \quad 31.30 \% \mathrm{Pt} \\
& 0.3581 \mathrm{~g} \text {. " } 0.1118 \mathrm{~g} . " \text { " } 31.22 \% \text { " } \\
& \text { Calc. for cholinechloroplatinate }\left[\left(\mathrm{C}_{-1}\left[\mathrm{H}_{1+} \mathrm{NOCl}\right)_{2} \mathrm{PtCl}_{4}\right] \quad 31.64 \% \mathrm{Pt}\right.
\end{aligned}
$$

The above results agree fairly with choline derivatives; the yield of the base was $6.75 \mathrm{~g}$. as chluroaurate.

\section{Summary.}

The chemical composition of the "Di-sake" compared with that of the ordinal "saké" is summarized as follows : 
(1) In the above experimental results the nitrogenous compounds isolated from 10 litres of "di-sake", are hypoxanthine-hydrochloride $(0.20 \mathrm{~g}$.), arginine nitrate $(4.60 \mathrm{~g}$.$) , cholinechloroaurate (6.75 \mathrm{~g}$.$) , and ammonia (3.52 g.),$ while the isolated bases from 25 litres of "saké" by Dr. K. Kurono, are cholinepicrate ( $3.8 \mathrm{~g}$.$) , histaminepicrate (0.15 \mathrm{~g}$.$) , lysinepicrate (0.52 \mathrm{~g}$.$) and am-$ monia ( $1.3 \mathrm{~g}$.$) . It is the most great difference that the "di-sake" contains$ large amount of arginine, which could not be isolated from the "saké".

(2) As regards the general composition, 1 fined great difference between the "di-sake" and the "sake" : in the former, the quantity of reducing sugar (chiefly glucose) and other extractive substances are considerably much more than those of the latter.

(3) In the "di-sake", the amount of non-protein substances is much more than those of the "sake".

(4) The reaction of "di-sake" is almost neutral, but in the "sake" remarkably acidic.

\section{Researches on the Electrolytic Reduction Potentials of Organic Compounds, Part XVI.}

Reduction potential of $p$-aminoazobenzene.

By

Masuzo Silkata and Isamu TaCHI.

(Received September 19, 1932.)

\section{Summary.}

The results of the investigation on the electrolytic reduction potential of $p$-aminoazobenzene with the polarograph and dropping mercury cathode at $25^{\circ} \mathrm{C}$ were as follows.

(1) Reduction potential of $p$-aminoazobenzene was more positive in lower concentration than that in higher concentration in every $\mathrm{PH}$ solution.

(2) Owing to the weak basic property of $p$-aminoazobenzene, there were two reduction potentials which were due to the dissociated and undissociated forms in some proper acidic solutions. In high acidic solution, $p$ aminoazobenzene changed to quinoid form which was demonstrated by spectrographic study. The reduction potential of quinoid form was more positive than that of azoid form and further, that of dissociated form more posi- 